\title{
HÁROM JEZIDI IMA
}

\author{
NÉMETH GYÖRGY ${ }^{1}$
}

\section{Three yazidi prayers}

The paper presents three yazidy prayers in Hungarian translation first time and a short commentary. The prayers are in Kurdish and express thankfullness and pleas for blessing and help.

\section{BEVEZETÉS}

A kurd nyelven beszélő jezidi közösségről és vallásról a nyugati világ a 19. századig tudomást sem vett. ${ }^{2}$ Amikor pedig valamennyire elterjedt a hírük, a muszlimok ellenséges értelmezése vált közismertté, miszerint vallásuk középpontjában az Ördög, a Gonosz tisztelete áll, ami a Páva-Angyal alakjának durva félremagyarázásából eredt. Sokat rontott hírükön Karl May, aki $A$ vad Kurdisztánon át ${ }^{3}$ című könyvében valamiféle nemes és jóindulatú, ördögtisztelő népként ábrázolja a jezidiket. $\mathrm{Az}$ 1965-ben ugyanezzel a címmel forgatott német film is ezt a szemléletet tette Európában ismertté. ${ }^{4}$

A jezidi vallás megismerésének hosszú ideig két komoly gátja volt. Az egyik az, hogy a hívőket kötelezte a takijje, a hallgatás parancsa, vagyis kívülállóknak nem árulhatták el hitük részleteit. A másik gát pedig az volt, hogy a hagyomány tiltotta a szent szövegek lejegyzését, amelyek szóban hagyományozódtak a szűk papi renden belül. Így maguk az egyszerű hívek sem ismerték különösebben az általuk gyakorolt vallás szent szövegeit, csak az imákat és az ünnepek szertartásait. Ez a titokzatosság magyarázza, hogy az 1930-as évektől elterjedt M. Guidi definíciója,

\footnotetext{
${ }^{1}$ ELTE, ORCID ooo-0oo1-878-8102.

${ }^{2}$ Kreyenbroek-Omarkhali 2016: 123.

${ }^{3}$ Durchs wilde Kurdistan, 1882.

${ }^{4}$ Rendezte Franz Josef Gottlieb.
} 
miszerint a jezidi vallás az iszlám aberrált formája..$^{5}$ Az 1990-es évektől radikálisan megváltozott a helyzet. Elöször Szaddám Huszein tömeggyilkosságai, majd az ún. Iszlám Állam szisztematikus népirtása döbbentette rá a jezidiket, hogy rögzíteni kell szent szövegeiket, mert ha megölik azt, aki a tudást átadhatná, elveszítik a sok évszázada örzött hagyományt. A másik ok, ami nyíltabbá tette őket, az volt, hogy a modernizálódás iraki Kurdisztánban is megindult, többen végeztek egyetemet, és tudatosan ápolták vallási hagyományaikat. ${ }^{6}$ A nyugati tudósokban inkább megbíztak, mint az őket fenyegető muszlimokban, és a keresztényeket afféle védöiknek tekintették, hiszen a nyugati keresztények a helyi, üldözött keresztény közösségek mellett a jezidiket is támogatták. A tömeges elüzetés a hagyományos vallási szokásokat is átalakította, de a várakozások ellenére nem gyengítette, hanem erősítette, és a kialakult helyzettel összeegyeztethetővé tette.7 Az erősödés azzal magyarázható, hogy a közösségnek nagyobb isteni segítségre volt szüksége, mint bármikor korábban. Azokon a szent helyeken ugyanis, pl. Lalisban, ${ }^{8}$ ahol szertartásaikat addig bemutatták, az ISIS tombolása idején nem gyülekezhettek össze, így ki kellett dolgozniuk valamilyen helyettes szertartást, amíg vissza nem térhetnek Irakba. Az emigrációban is változtatni kellett a szertartások helyszínén, hiszen egyedül Németországban nagyjából 200 ooo jezidi él.

Az alábbiakban három rövid imát mutatok be. A jezidi vallásról és magukról a jezidikről ugyanis Magyarországon csak az ISIS pusztításai miatt esett szó, de elmaradt a vallás részletesebb bemutatása. Ez a forrásközlés természetesen nem vállalkozhat erre a feladatra, de ráirányítja a figyelmet erre az elvégzendő feladatra.

\section{A hit szimbóluma (Sahdá díní)}

„Hitem tanúsága egy isten (Alláh),

Szultán Seik Adi a királyom,

Szultán Jezid a királyom,

Malak-Távúsz [Páva-Angyal] a hit jelképe, és a hitem jelképe.

Valóban, isten akaratából jezidik vagyunk,

Nevünket Szultán Jezidtől kaptuk,

Dicsőitsük Istent, elégedettek vagyunk vallásunkkal és közösségünkkel."9

${ }^{5}$ Kreyenbroek-Omarkhali 2016: 123.

${ }^{6}$ A legterjedelmesebb gyüjtemény Omarkhali 2017: 625 oldalon mutatja be az Örményországban, Észak-Irakban és Németországban gyűjtött szövegeket. Vö. Bruinessen 2018.

7 Spät 2016: 162-174.

${ }^{8}$ Spät 2004: 147-157.

${ }^{9}$ Asatrian-Arakelova 2014: 3. 
Alláh nem azonos a muszlim istennel, a név csak azt jelzi, hogy egyetlen isten létezik, mint a muszlimoknál. Ő azonban három különböző szimbolikus formában is megjelenhet, ami miatt ezek valamiféle szentháromságnak tekinthetők. ${ }^{10}$

Seik Adi bin Muszafir történelmi személyiség, a proto-jezidi közösség alapítója. A 12. században Lalis völgyében (a jezidik szent helyén) szúfi dervis kolostort alapított, és az ottani, Ad-Adavijja dervisrend nagyon nem ortodox muszlim vallási gyakorlatából alakult ki a jezidi vallás. ${ }^{11}$ Seik Adit öreg emberként ábrázolták.

Szultán Jezid, a nép névadója, fiatal férfiként ábrázolták.

Malak-Távúsz [Páva-Angyal] madár, többnyire páva, de olykor kakas vagy éppen galamb képében elképzelt isteni lény.

\section{Isten dicsőitése (Madh’é Khvadé)}

„Ó, Uram, örökkévaló vagy,

Kegyelmes vagy,

Méltóságteljes vagy,

Ösi vagy,

Minden isten istene vagy,

Az isten, aki a jóságot birtokolja,

Az égi mennyország istene vagy,

Kezdettől fogva ősi,

Minden isten istene vagy.

Te vagy a menedék és a hatalom,

Te vagy a lelkek és az emberek istene,

Az ég és a trón istene,

A szentség birodalmának istene,

Minden isten istene vagy.

Te vagy a menedék és a hatalom,

Senki sem tudja, mi vagy te,

Minden isten istene vagy,

Nincs otthonod, nincs menedéked,

Nincs színezésed, sem színed,

Nincs hangod sem hangzásod,

Senki sem tudja, mi vagy te,

Minden isten istene vagy.

A szertartások és az imák ura vagy,

\footnotetext{
${ }^{10}$ Uo.

${ }^{11}$ Spät 2011a: 14.
} 
Lelket adsz az embereknek és elszakítod a lelküket,

Te uralkodsz a királyok és a nép fölött,

Te uralkodsz az egész világ felett,

Te teremtetted Jézust és Máriát,

Te teremtettél minket, jezidiket, Ádám ágyékából,

Minden isten istene vagy..."12

\section{Reggeli ima}

„Ó, Isten (Khwadé), gyere, mentsd meg

A hetvenkét népet,

Rabokat,

Szenvedőket,

A szegényeket és a reményvesztetteket,

Azután gyere, és egyedül

A mi népünket, a jezidiket mentsd meg!"13

A hetvenkét népet - A Genezis 10. hetven, de a rabbinikus hagyomány szerint hetvenkét népet sorol fel. A Septuaginta, az Ószövetség görög fordítása szövegében hetvenkét nép szerepel. Jézus ezért küldi ki hetvenkét tanítványát, hogy tanítsák a népeket (Lk. 10. 1.). A jezidi ima nyilván az ószövetségi és a keresztény hagyományra támaszkodik. ${ }^{14}$

Szenvedőket, a szegényeket és a reményvesztetteket - Ugyanazokat, akiket Krisztus is felsorol ( $\mathrm{Lk} \mathrm{6,20-23).}$

\footnotetext{
${ }^{12}$ Asatrian-Arakelova 2014: 5.

${ }^{13}$ Uo. 5-6.

${ }^{14}$ A hetvenkét nép a Rastafari vallásban is megjelenik. Ras Michael Sewenty-two nations címü dalának szövege egyértelműen az Ószövetségre támaszkodik: „Seventy two different nations / Bow before Jah presence / For He's the King of Kings, He's the Lord of Lords / Conquering Lion of Judah."
} 


\section{A KORSÓ GYERMEKE}

Tudomásom szerint eddig egyetlen jezidi vallási szöveg jelent meg magyarul, a Spät Eszter által a jezidi vallástudóstól, Faqir Hádzsitól gyüjtött történet Ádámról. ${ }^{15}$ Eszerint Isten megteremtette Ádámot, és homlokába költöztette Sejk Szin angyalt. Isten egy idő után megparancsolta a Páva Angyalnak, hogy hozza ki Ádámot a Paradicsomból, hogy megszülethessen az ember. A Páva Angyal csellel rávette Ádámot, hogy egyen a tiltott búzából. Ettől azonban belei működni kezdtek. Azért kellett elhagynia a Paradicsomot, nehogy összemocskolja. Páva Angyal kivette Ádám homlokából a fényt. Ádám emiatt Sátánnak nevezte Páva Angyalt, ezt a szót azóta a jezidiknek tilos kiejteni. Páva Angyal olyan népet szeretett volna, amely nem káromolja őt. Az Ádám homlokából kivett isteni fényt egy korsóba helyezte, és kilenc hónappal később világra jött Sehid bin Dzser, a jezidik őse. A jezidik nem Évától, csak Ádámtól származtatják magukat, és nem is házasodhatnak össze az első emberpártól származó kétszer hetvenkét gyermek leszármazottaival.

Egy másik, elterjedtebb változat szerint Éva azt állította, hogy a gyermekek az ő méhéből születtek, ezért azok csak az ő gyermekei. Ádám szerint viszont a férfi magból származtak. Vitájuknak azzal vetettek véget, hogy egy-egy korsóban elhelyezték Ádám, illetve Éva magját, és lezárták azokat. Kilenc hónap múltán Ádám korsójából gyönyörü kisfiú, Sehid bin Dzser született meg, Éváéból azonban csak kukacok és férgek. Ádám maga szoptatta a kisfiút (ezért van a férfiaknak is mellbimbójuk), aki felserdülve a jezidik ősapja lett.

A fentiek alapján nyilvánvaló, hogy a jezidi vallást nem lehet valamiféle eltorzult iszlámként felfogni. A jezidik összeolvasztottak egy sereg vallási tradíciót a zsidóságtól a kereszténységen keresztül a szúfi iszlámig és a gnosztikusokig, és a mai napig őrzik ezt a sajátos, csak népük körében tisztelt vallást.

\section{IRODALOM}

Asatrian, G. S. - Arakelova, V. (2014). The Religion of the Peacock Angel. The Yezidis and their Spirit World. London - New York, Routledge.

Bruinessen, M. v. (2018). Omarkhali, K. The Yezidi Religious Textual Tradition: From Oral to Written. Categories, Transmission, Scripturalisation and Canonisation of the Yezidi Oral Religious Texts. Kurdish Studies 6, 155-167.

\footnotetext{
${ }^{15}$ Spät 2011a: 15-16. Spät írásainak egy részét felsorolom a bibliográfiában. A legkiválóbb jezidi szakértők egyike, terepmunkái során nagyon sok anyagot gyüjtött, nemcsak a szöveges emlékeket, hanem a vallás tárgyait is, vö. Spät 2019. Minthogy valamennyi írását hosszú ideje csak angolul írja, személyesen nem vállalkozott rá, hogy a Forrás rovatban bemutasson egy jezidi vallási szöveget.
} 
Omarkhali, K. (2017). The Yezidi Religious Textual Tradition: From Oral to Written. Categories, Transmission, Scripturalisation and Canonisation of the Yezidi Oral Religious Texts. Wiesbaden, Harrassowitz.

SpÄт, E. (2002). Shehid bin Jerr, Forefather of the Yezidis and the Gnostic Seed of Seth. Iran and the Caucasus 6(1-2), 27-56.

SPÄT, E. (2004). The Festival of Sheikh Adi in Lalish, in the Holy Valley of the Yezidis. Annual of Medieval Studies at CEU (Central European University, Budapest) 10, 147-157.

SPÄT, E. (2004). Changes in the Oral Tradition of the Yezidis of Iraqi Kurdistan. The Journal of Kurdish Studies, 5, 73-83.

SPÄT, E. (2005). The Yezidis. London, Saqi Books.

SpÄT, E. (2008). Late Antique Literary Motifs in Yezidi Oral Tradition: The Yezidi Myth of Adam. Journal of American Oriental Society 128(4), 663-679.

SPÄT, E. (2008). Religious Oral Tradition and the Literacy among the Yezidis of Iraq. Anthropos 103 (2), 393-404.

SPÄT, E. (2009). The Role of the Peacock "Sanjak" in Yezidi Religious Memory. In I. Barbiera et al. (eds.): Materializing Memory: Archeological Material Culture and the Semantics of the Past. Oxford, Archaeopress, 105-116.

SPÄT, E. (2010). Late Antique Motifs in Yezidi Oral Tradition. Piscataway, NJ, Gorgias Press.

Spät, E. (2011). The Song of the Commoner: The Gnostic Call in Yezidi Oral Tradition. In J. A. van den Berg et al. (eds.): Search of Truth: Augustine, Manichaeism and Other Gnosticism. Leiden, Brill, 663-683.

SPÄт, E. (2011a). Egy gnosztikus mítosz a modern Közel-Keleten. A jezidi „korsó gyermeke” és Séth. Ókor 10/2. 14-24.

SpÄт, E. (2013). Religion and Oral History: The Origin Myth of the Yezidis. In C. Allison, C. and P. Kreyenbroek (eds.): Remembering the Past in Iranian Societies. Göttinger Orientforschungen Iranica Neue Folge 9. Wiesbaden, Harrassowitz, 33-45.

Spät, E. (2013). On Soil and Jinn. Ritual Practices and Syncretism among the Yezidis of Northern Iraq. In Andreas H. Pries et al. (eds.): Rituale als Ausdruck von Kulturkontakt - „Synkretismus“ zwischen Negation und Neudefinition. Studies in Oriental Religions 67. Wiesbaden, Harrassowitz, 111-129.

SPÄт, E. (2016). Persecution and the development of Yezidi ritual life. Kurdish Studies 4/2, 155-175.

SpÄT, E. (2019). Gifts from the sky: Yezidi Sacred Objects as Symbols of Power, Tools of Healing and Seals of Divine Favour. In É. Pócs (ed.): Charms and Charming. Studies on Magic in Everryday Life. Ljubljana, Zalozba, 213-236. 